\title{
The evolving role of the pension fund trustee
}

Received (in revised form): 15th July, 2002

\section{Kate Richards}

was admitted as a solicitor in 1990 and joined the Nabarro Nathanson pensions team in 1995, becoming a partner in 2001. Her recent experience includes drafting pensions documentation, ongoing day-to-day advice to scheme employers and trustees, scheme mergers and winding-up, and advising on the pensions aspects of corporation transactions. Kate is an elected Committee Member of the National Association of Pension Funds (NAPF), West London Group, and was selected as a member of the investment committee of the Association of Pension Lawyers.

\begin{abstract}
This paper reviews the key proposals of the Myners Report for trustees of defined benefit (DB) and defined contribution (DC) occupational pension schemes and the Government's proposals for legislation. It considers the proposed raised duty of care for pension scheme trustees and the implication of the adoption of the raised standard upon the role of the trustee. It also examines the impact of the principles and the raised standard of care upon trustee decision-making and the practical outcome of the proposals for trustees.
\end{abstract}

Keywords: The Myners Report; asset allocation; explicit mandates; activism; performance measurement; Myners principles; the 'prudent expert' standard; duty of care; trustee training; statement of investment principles

\section{INTRODUCTION}

This paper is about the evolving role of the pension scheme trustee. This is a wide-ranging topic. It has involved an examination of recent developments which could change the trustee's role and contrasts them against the current legal position.

\section{The Myners Report}

One of the key areas in which trustees' duties and expertise have been put under the microscope is in the field of investment as a consequence of the

Tel: +44 (0)20 524 6000; Fax +44 (0)20 524 6524; e-mail:

k.richards@nabarro.com findings of the Myners Report. The main focus of this talk is upon Myners and the potential impact of the changes proposed upon the role of trustees.

Paul Myners issued his report, entitled
'Institutional investment in the United Kingdom: A Review', on 6th March, 2001. The central proposal of the review is a short set of clear principles of investment decision-making. The report provides that the Code is not mandatory but if a fund chooses not to comply with the principles, this would have to be disclosed to the members.

The Chancellor, Gordon Brown, in his budget speech in Spring 2001, referred to the Myners Report and endorsed its recommendations in their entirety. He said:

'To promote long term investment and to protect investors, I have accepted the recommendations of the Myners report....I support the challenge to the industry $\mathrm{Mr}$ Myners has laid down and his proposal that 
we should be prepared to legislate as necessary to achieve the improvements he prescribes.'

He also went on to say that:

'We will ensure both a strengthened role for pension fund trustees and a clearer duty on fund managers to promote beneficiaries' interests'.

\section{Initial reaction to the report}

Broadly, the Myners Report was reasonably well received by the pensions industry, although key drawbacks identified were its big scheme focus and cost. No cost/benefit analysis was carried out by Myners. In particular, the cumulative cost of the range of proposals made was not assessed.

The Myners Report was submitted for consultation and interested parties were asked to comment upon the principles in the proposed Code by 15th May, 2001.

\section{The Government's response to consultation}

The results of the Government's consultation were published on 2nd October, 2001. The Government issued a revised set of principles and expects that pension funds will publicly disclose their compliance with these on a voluntary basis. Trustees will be expected to explain to members why the fund has chosen to depart from any of the principles.

\section{Proposals for legislation}

The Government intends to legislate to enact two of the recommendations contained in the Myners Report. The first area concerns trustees' duty of care. The Government proposes to legislate to raise the standard of care required of trustees.
The second area concerns 'shareholder activism'. The Government intends to legislate to incorporate into UK Law the principles contained in US Law (the Employment Retirement Income Security Act 1976 (ERISA)) on shareholder activism, making intervention in companies, where it is in the shareholders' and beneficiaries' interests, a duty.

The Government issued consultation papers on the above topics on 4th February, 2002. Primary legislation may be needed to implement these proposals. A third area now earmarked for possible legislation concerns the proposal that there should be a statutory requirement for funds to have independent custodians. This proposal is outside the scope of this paper.

\section{Government review of implementation of Myners in March 2003}

While the Myners Code of Practice is currently voluntary, the Myners review also recommended that there should be a public assessment of the effectiveness of the principles in bringing about change. This review will be initiated in March 2003, as recommended. At that stage, if behaviour has not changed on a voluntary basis, the Government has stated its intention to legislate to ensure implementation.

\section{Myners code of practice}

In his report, Myners set out ten or so key principles for DB and DC schemes which encapsulate the recommendations of the report and attempts to codify a model of best practice.

Table 1 sets out a summary of the proposed principles for DB and DC schemes in the context of trustees' roles and duties as restated by the Government in its response to the Myners review. 
Table 1: DB schemes

\begin{tabular}{|c|c|}
\hline Principle & Scope \\
\hline $\begin{array}{l}\text { Effective } \\
\text { decision-making }\end{array}$ & $\begin{array}{l}\text { Those who take the investment decisions must have the skills, information and } \\
\text { resources necessary to take them effectively. Where trustees elect to take } \\
\text { investment decisions they must have sufficient expertise and appropriate training to } \\
\text { evaluate critically any advice they take. Trustees must ensure they have sufficient } \\
\text { in-house staff to support them in their investment responsibilities. Trustees should } \\
\text { be paid (unless there are specific reasons to the contrary). It is good practice to } \\
\text { have an investment sub-committee to provide focus. Trustees should conduct } \\
\text { self-assessment of their skills/structures and processes to determine whether they } \\
\text { can carry out their role effectively. Trustees should adopt a forward-looking business } \\
\text { plan. }\end{array}$ \\
\hline Clear objectives & $\begin{array}{l}\text { Overall fund investment objectives should be set taking into account the trustees' } \\
\text { best judgement of what is necessary to meet the fund's liabilities and taking into } \\
\text { account likely contributions to be received into the fund and the trustees' attitude } \\
\text { to risk, specifically their willingness to accept market underperformance due to } \\
\text { market conditions. Objectives must relate to fund liabilities (not peer group } \\
\text { performance). }\end{array}$ \\
\hline $\begin{array}{l}\text { Focus on asset } \\
\text { allocation }\end{array}$ & $\begin{array}{l}\text { Strategic asset allocation should receive more attention, reflecting its importance to } \\
\text { achieving the fund's investment objectives and the full range of investment } \\
\text { opportunities should be taken into account, including private equity. The reference } \\
\text { point for asset allocation should be the fund's own characteristics not asset } \\
\text { allocation of other funds. }\end{array}$ \\
\hline Expert advice & $\begin{array}{l}\text { Contracts for actuarial and investment advice should be open to separate } \\
\text { competition. }\end{array}$ \\
\hline Explicit mandates & $\begin{array}{l}\text { An explicit written mandate must be agreed with managers and must cover topics } \\
\text { such as: objectives, benchmarks, risk parameters that fit with the overall investment } \\
\text { objectives and risk tolerances; the manager's investment approach; timescales of } \\
\text { measurement and evaluation such that the mandate will not be terminated before } \\
\text { expiry of the evaluation timescale for underperformance alone. No financial } \\
\text { instruments to be excluded, without clear justification, from the mandate and the } \\
\text { trust deed and rules. Trustees must have a full understanding of transaction-related } \\
\text { costs incurred, including commissions. Proper cost control strategies should be } \\
\text { implemented. Trustees should not, without good reason, permit soft commissions to } \\
\text { be paid in respect of their fund's transactions. }\end{array}$ \\
\hline Activism & $\begin{array}{l}\text { The US Department of Labor Interpretative Bulletin on activism (ie the policy on } \\
\text { proxy voting policy or guidelines) should be incorporated into the mandate and the } \\
\text { scheme's trust deed. Managers should have an explicit strategy concerning } \\
\text { circumstances in which they will intervene in a company, the approach taken and } \\
\text { methods of evaluation of the strategy. }\end{array}$ \\
\hline $\begin{array}{l}\text { Appropriate } \\
\text { benchmarks }\end{array}$ & $\begin{array}{l}\text { Appropriate benchmarks should be agreed by trustees with the managers avoiding } \\
\text { sub-optimal investment strategies. Trustees should consider, in relation to each } \\
\text { asset class, whether active or passive management is more appropriate and allow } \\
\text { managers to pursue active strategies (if chosen) which freely allow managers the } \\
\text { potential to achieve higher returns. }\end{array}$ \\
\hline $\begin{array}{l}\text { Performance } \\
\text { measurement }\end{array}$ & $\begin{array}{l}\text { Trustees must arrange for measurement of fund performance and formal assessment } \\
\text { of their own procedures and decisions plus those procedures and decisions } \\
\text { delegated to their advisers and managers. }\end{array}$ \\
\hline \multirow[t]{2}{*}{ Transparency } & $\begin{array}{l}\text { A much more detailed statement of investment principles (SIP) should be produced } \\
\text { covering: }\end{array}$ \\
\hline & $\begin{array}{l}\text { - who takes decisions and why this structure has been selected } \\
\text { - the investment objective } \\
\text { - the scheme's asset allocation strategy and how it has been arrived at } \\
\text { - adviser's and manager's mandates } \\
\text { - fee structures and why these have been selected. }\end{array}$ \\
\hline Regular reporting & $\begin{array}{l}\text { The SIP should be published together with the results of monitoring of advisers and } \\
\text { managers. Key information from the SIP and monitoring should be sent to scheme } \\
\text { members including an explanation of why the fund has decided to depart from any } \\
\text { of the principles. }\end{array}$ \\
\hline
\end{tabular}


Table 2: Differences and additions reflecting the different structure of DC schemes

\begin{tabular}{ll}
\hline Principle & Scope \\
\hline $\begin{array}{l}\text { Effective } \\
\text { decision-making }\end{array}$ & $\begin{array}{l}\text { Trustees must ensure that where members are given a choice regarding investment } \\
\text { issues, sufficient information should be given to them to allow an appropriate choice } \\
\text { to be made. }\end{array}$ \\
Clear objectives & $\begin{array}{l}\text { In selecting funds for members, trustees should consider investment objectives, } \\
\text { expected returns, risks and other relevant characteristics of each fund so that they } \\
\text { can publish their assessments of these characteristics for each fund. They should } \\
\text { also satisfy themselves that they have taken their members' circumstances into } \\
\text { account and are offering a wide enough range of options to satisfy the reasonable } \\
\text { return and risk combinations that are appropriate for most members. }\end{array}$ \\
$\begin{array}{l}\text { Choice of } \\
\text { default fund }\end{array}$ & $\begin{array}{l}\text { Appropriate investment objectives should be set by the trustees for any default } \\
\text { option offered under the scheme, including expected returns and risks. }\end{array}$ \\
Explicit mandates & $\begin{array}{l}\text { Trustees would be required to communicate to the members the investment } \\
\text { objective, benchmark and risk parameter for each fund and the manager's approach } \\
\text { in attempting to achieve the objective. }\end{array}$ \\
$\begin{array}{l}\text { Transparency and } \\
\text { regular reporting }\end{array}$ & $\begin{array}{l}\text { The statement of investment principles should also be strengthened for DC schemes } \\
\text { as for DB schemes but including also information about each fund option's } \\
\text { investment characteristics; the default option's investment characteristics and why it } \\
\text { has been selected and the agreements with all advisers and managers. }\end{array}$ \\
\hline
\end{tabular}

\section{DC schemes - Proposed principles}

A similar set of principles is also recommended for DC schemes with some specific differences and additions reflecting the different structure of DC schemes as compared to DB and specifically the fact that many schemes give members a choice of investment media. Table 2 identifies only the differences and additions.

\section{Exceptions to application of the Myners principles}

The Government has acknowledged that the principles Myners proposed may not be suitable for all types of schemes in the light of cost and structural issues.

Particular concerns were raised for small schemes. The Government has made it clear, however, that small schemes should nevertheless seek to comply where practicable with the principles and, if unable to do so, that they should explain to members why they have not fully complied. Insured schemes are excluded from compliance with the principles on grounds that trustees of insured schemes have effectively delegated responsibility for all investment decisions except the choice of provider.

\section{Impact upon trustees}

Most of the principles impact directly upon the role of the pension fund trustee in the investment process. But then Paul Myners is definitely of the view that changes to the trustee role are ripe in coming. He remarked around the time the report came out as follows: 'I respect the sincerity of the view that being a trustee is like being a scout master or a churchwarden. But it's hardly the basis on which to think about the management of $£ 800$ billion of assets. ${ }^{\prime 1}$

\section{Review of the proposed principles}

This paper will consider the likely impact of the key proposals in the Myners Report upon the role of the pension fund trustee. 


\section{Effective decision-making}

We turn first to the investment decision-making process. In the report, Paul Myners identified what he described as a 'serious problem' ie the lack of investment understanding among trustees. His contention was that it led to poor decision-making in the investment context. Trust law, he stated, 'was not designed to introduce the expertise likely to be required in the management of substantial pools of pension assets' (paragraph 2.24 of the Myners Report).

\section{Adoption of the 'prudent expert' standard}

He recommended that trustees should be required to become 'prudent experts' adopting the standards set out in US legislation and that, if they do not have such expertise, they should acquire it. Alternatively, trustees should delegate the decision to a person or organisation which they believe does possess this level of skill and care.

The US federal legislation referred to codifies traditional fiduciary responsibilities into a single nationwide standard. A fiduciary is defined as a person or entity that: 'exercises any discretionary authority or discretionary control respecting management of such plan'.

The duties of fiduciaries are defined as follows: 'a fiduciary shall discharge his duties with respect to a plan with the care, skill, prudence, and diligence under the circumstances then prevailing that a prudent man acting in a like capacity and familiar with such matters would use in the conduct of an enterprise of a like character and with like aims. ${ }^{2}$

\section{The 'prudent man' test}

The current position with regard to the standard of expertise required of trustees under English law is that of the 'prudent man'. This well-known principle is explained in the case of Re Whiteley ${ }^{3}$ as follows:

'In the selection of investments within the terms of his trust [the trustee] must use the care and caution which an ordinary man of business...would exercise in the management of his own property.'

There are other more recent cases that have reiterated that principle such as: Bartlett v. Barclays Bank Trustee Co Ltd $(\text { No } 1)^{4}$; Cowan v. Scargill ${ }^{5}$; Steel v. Wellcome Custodian Trustees Limited ${ }^{6}$; Nestlé v. National Westminster Bank plc.

The case law indicates that prudence requires more than mere honesty, good faith and sincerity. Trustees are expected to demonstrate a level of proficiency and competence. Exactly what that level is will vary from case to case.

\section{'Familiar with the issues'}

The 'prudent expert' standard or the requirement to be 'familiar with the issues' is not fully explored in Myners' report and no clear indication is given as to how an ordinary trustee could successfully meet this standard.

The Government has now given some guidance in its consultation document entitled 'Pension Scheme Trustees, "Familiar with the issues concerned", A Consultation Document' as to the standards it will require of the trustees in terms of the skill, duty of care and familiarity with the issues concerned.

The new standard of care is not expressed as a 'prudent expert' standard but one of being 'familiar with the issues concerned'. It is envisaged that the standard will be as follows (paragraph 15):

- pension scheme trustees will be required to act with the care, skill, 
prudence and diligence under the circumstances then prevailing that a prudent person acting in a like capacity and familiar with such matters would use in the conduct of an enterprise of like character and of like aims. (This is taken from ERISA section 404(a)(1)(B));

- In addition, where a pension scheme trustee has, or holds himself out as having, any special knowledge or experience, he must exercise such care and skill as is reasonable in the circumstances (section1(1)(a) Trustee Act 2000 refers); and

- where a pension scheme trustee acts in the course of a business or profession, he must exercise such care and skill as is reasonable in the circumstances, having regard to any special knowledge or experience as it is reasonable to expect of a person acting in the course of that kind of business or profession (section 1(1)(b) Trustee Act 2000 refers).

The consultation paper explains that the new duty of care is intended, to a large extent, to reflect the flexible duty of care imposed generally by common law and the Trustee Act 2000, while recognising that a higher standard of care is required of those involved with the investment of occupational pension scheme assets. The new duty requires expressly that trustees of occupational pension schemes must be familiar with the issues in respect of which they are responsible. Failure to use the increased standard of care when taking investment decisions could be open to challenge in the Courts. It is not clear when legislation implementing the new standard of care will be introduced, but this is unlikely to happen before 2003. It is possible that the Government may decide against legislating in this area and rely upon voluntary compliance. This would be consistent with the
Government's stated intention to 'simplify' pensions regulation.

\section{Duty to seek advice}

How does Myners' conclusion that trustees need more expertise to take effective decisions sit with their existing duties to seek advice?

The current position is that trustees are already bound by trust law to seek advice upon those matters where they are not experts, which would normally include investment matters. They also have statutory duties in this regard under the Pensions Act 1995. This requires that trustees 'obtain and consider' advice when:

- preparing or revising the SIP (section 35(5))

- before investing in any manner (other than in a manner mentioned in Part I of Schedule I to the Trustee Investments Act 1961).

The advice must be proper advice on the question whether the investment is satisfactory having regard to the principles of diversification and suitability (section 36(2)) and the principles mentioned in the SIP.

Also, trustees must decide at what intervals they should take proper advice in relation to the retaining of an investment given the circumstances and the nature of the investment (section 36(4)).

As mentioned above, the Myners Report acknowledges the existing legislation on advice-seeking but is sceptical as to whether this is a total substitute for the trustees raising their level of expertise. Myners is concerned that trustees are not critical enough of the advice given by consultants and investment professionals so that effectively decisions are based upon 
advice given as a rubber-stamping exercise. He maintains that if trustees were better educated, this problem would fall away, leading to more informed and effective decision making.

The Government agrees with Myners and has most recently articulated its agreement in its consultation paper dealing with the new standard of care. The Government confirms that pension scheme trustees 'should not be required to become investment experts and should be entitled to make use of the expertise of others' (paragraph 12). However, the Government considers that trustees should have sufficient expertise to be able to evaluate whether advice is 'complete, up to date and based on appropriate assumptions and should exercise their own judgement when considering and acting upon the advice - irrespective of the source of that advice (the fund manager, scheme administrator or any other adviser)' (paragraph 12).

It therefore proposes that all trustee boards should consider which investment decisions they wish to take and which decisions they do not wish to take. Where they wish to take a decision, they should ensure that they do, in fact, have the skills and resources to take decisions effectively.

Where trustees decide that it is not practical or desirable for them to take the necessary steps to reach the skill level required, they must delegate responsibility for this decision to someone who does have the skills and resources to take it effectively.

The Government has not indicated that the requirements to seek advice under the Pensions Act in preparing the SIP and when taking an investment decision will be amended. Therefore, even where trustees have the requisite level of expertise required by the new raised duty of care, it would seem that they will still be obliged to seek additional advice in accordance with the existing requirements.

While the gaining of greater expertise for trustees is to be welcomed, it remains to be seen whether this will necessarily mean that trustees will effectively challenge advice given. Under the current law, trustees would not be acting properly if advice were merely rubberstamped and a responsible trustee should ask relevant questions to ensure that he/she understands the advice and therefore is able to act upon it. Having said this, in practice most trustees, even if they were sufficiently professional and knowledgeable to meet the 'prudent expert' standard, would be likely to feel exposed if they were to take professional advice and then not follow the advice given (unless there was very good reason). The professionals will always have the advantage of broader, more wide-ranging experience than trustees. However, the new duty may require trustees to be more proactive and to seek further advice if they consider in their own judgement that the first adviser's advice is incorrect or insufficient.

\section{Delegation to persons who have the skills and resources to take effective investment decisions}

The Government has said that trustees are fully entitled to decide that for some or even all investment decisions, it is not practical or desirable for them to take the necessary steps to reach the new higher duty of care.

Most investment decisions are already delegated to fund managers on account of the restrictions presented by the regulatory regime which disallows trustees of pension schemes (unless authorised) from managing investments involving routine or day to day decisions. ${ }^{8}$ The Myners Report does not 
explore in any depth the interaction between the regulatory regime (which effectively forces trustees to delegate their investment functions to FSA authorised fund managers) and trustees' investment decision-making.

\section{Section 34(2) of the Pensions Act 1995}

Trustees' powers of delegation are reinforced by the statutory power under Section 34(2) of the Act which allows trustees to delegate any of their investment discretions to an

FSA-authorised fund manager (regardless of the provisions of the trust deed). Provided trustees satisfy certain statutory conditions in making the delegation, they will not be responsible for the act or default of the manager in exercising the investment discretion.

Trustees may consider that, rather than satisfy the new higher duty of care, they would prefer to delegate more of their investment decisions. What category of decisions would usually fall to be delegated which would tend not to be delegated to fund managers? Decisions that they might in future decide to delegate may be the choice of DC funds or decisions concerning the finalisation of managers' mandates or other 'strategic' decisions. A person to whom such duties are delegated could be seen as a new breed of 'manager of managers', effectively adding another layer of professional involvement in the investment decision making process.

Under current legislation trustees are only permitted to delegate investment discretions to persons who qualify as 'fund managers' for the purposes of the Pensions Act 1995. The current legislation may be too restrictive to allow the trustees sufficient scope in their choice of delegate as it is not clear that perhaps the most obvious candidates for the job of 'manager of managers' ie the investment consultants would meet the definition of 'fund manager'.

Another area of uncertainty is in the preparation of the SIP. The 1995 Act does not permit delegation of preparation of the SIP to a third party. In preparing the SIP, investment decisions are taken in a strategic sense. Trustees (or at least some of them) may be forced to meet the new standard of care standard unless the statutory framework is altered to allow them to delegate preparation of the SIP.

Overall it would seem that quite extensive amendment of the Pensions Act 1995 will be needed in order to permit the delegation of all trustees' 'investment functions'.

\section{More employer-appointed trustees?}

One consequence of the introduction of a higher standard of care is that trustees may turn to the employer to appoint trustees to the trustee board with the requisite skills and experience to assist in the formulation of investment policy. It is more likely that such skills will be found from the employer side than from those elected from the membership. Such skilled trustees could, as recommended by Myners, form an investment sub-committee to take investment decisions which would be dominated by employer-appointed trustees. The Government's consultation paper on the higher duty of care makes clear that although decisions may be delegated to investment sub-committees, the pension scheme trustees will continue to retain responsibility and legal liability for the decisions of investment sub-committees (paragraph 24). The question that arises is whether the trustees as a whole will then be judged by the raised duty of care even though their investment functions were delegated to an 
investment sub-committee (paragraph 24). The Government is consulting upon this issue and whether or not the new duty will apply individually or collectively. Where a corporate trustee is in place this would appear not to be an issue because decisions are taken collectively by the trustee directors as one legal entity.

\section{Role of member-nominated trustees}

There is a potential conflict between the introduction of the raised duty of care and the policy of encouraging the participation of lay individuals in the running of pension schemes as member-nominated trustees (MNTs).

The Government's clear and established policy objective in this regard is that member-nominated trustees should be a mandatory requirement (see the Department of Social Security's (now the Department for Work and Pensions) Consultation Paper entitled 'Member-nominated Trustees and Directors - A Consultation Document 1999'). At the date of writing, the Government has postponed the introduction of the proposed new MNT legislation pending the production of Alan Pickering's report on simplification in Summer 2002.

The Government has confirmed its support for MNTs by stating that:

'under no circumstances do these proposals create any requirement for trustees to become "professional" in the sense that they earn their living from being trustees of various pension schemes. The Government has made clear that it believes that the system of Member Nominated Trustees is a valuable and important one, which should continue, unchanged. In that sense it is fully in favour of the continuing amateur status of trustees' (paragraph 48 of the Government's Response).
However, unless MNTs have the requisite level of expertise, Myners and the Government propose that there should be a requirement for them not to continue to take investment decisions themselves, even with advice. There is a conflict between the two policy objectives as, inevitably, if more formal training requirements are introduced, it would seem likely that MNTs would be more reluctant to come forward as candidates.

\section{Trustee training - Mandatory or not?}

In order to reach the new standard of care, the Government has stated that 'appropriate training' must be obtained by trustees taking investment decisions. This represents a change of Government policy as, up until now, trustee training has never been a mandatory requirement.

Myners' survey of 226 trustees revealed that 26 per cent of trustees received less than one day's training when they first became trustees and 69 per cent received two days or less. Forty-four per cent said that they had not attended any courses since their initial 12 months of trusteeship (paragraph 2.7 of the Myners Report).

The above results reveal great scope for improvement in the amount of training in every aspect of trusteeship that trustees receive. Reasons for not making training a mandatory requirement are that it would be an additional cost burden and the policing of such a requirement would, in practice, be difficult and costly.

This issue was debated in Parliament during the passage of the Child Support, Pensions and Social Security Act 2000 (House of Lords, 15th May, 2000). An amendment was proposed in the House of Lords to the effect that all trustees must attend an approved training course within six months of being appointed or face 
removal. It would also have required the Government to prescribe in regulations the content of such training. Although the Government agreed to put the matter to consultation, the view expressed was that the existing requirement in the Employment Rights Act 1996 (Section 58) that employees should be given paid time off to undertake training was sufficient to encourage training opportunities to be taken.

Ultimately the amendments to the Act were rejected on the basis that employers would oppose the additional cost and were hostile to it. The Goode Committee reached similar conclusions in its 1993 report upon Pensions Law Reform (see paragraph 4.5.65 of the Report of the Pension Law Review Committee published by HMSO, September 1993). However, in future, where trustees do decide to take investment decisions themselves they will need to adhere to the 'appropriate training' requirements. In its consultation paper on the new raised duty of care, the Government discusses the issue of training, seeking responses upon 'the nature of the required training, how the training might be provided and whether there would be merit in an industry accreditation scheme'.

\section{Should trustees be paid?}

As has been well documented in the press, the Myners Report also proposed that, in general, paying trustees is good practice and that because the task is a serious and complex one, it requires considerable time and energy and should be rewarded (paragraph 2.30 of the Myners Report).

The implication of these statements above is that, unless a trustee is paid, it is less likely that the job will be carried out with the seriousness it merits and that its complexity will be beyond the average 'amateur' trustee. The Government will have difficulty in claiming its support for 'amateur' trustees such as MNTs in an environment where payment is a 'badge' of professional status.

Over recent months the Government has reviewed its proposal concerning payment of trustees. This recommendation is not mentioned in the consultation paper on the new duty of care at all. While still maintaining that payment should be given 'serious consideration', the Government appears to be focusing on what it considers to be the real problem, which is a shortfall of time rather than money and that employers should allocate sufficient time to their employees who are pension scheme trustees, to enable them to prepare properly for meetings and to keep abreast of current issues as well as training.

\section{Increased protections for trustees?}

The consequence of increasing the duty of care of trustees (and hence their potential liabilities) is that trustees will require greater protections from liability via the trust documentation where this is possible or via insurance. I would also anticipate that most trustees would wish to operate within a corporate structure as the case law indicates that there is greater protection from liability where a corporate trustee is in place. The attractiveness of the corporate structure may increase if liability for breach of the new duty of care is applied to trustees on an individual basis.

In the Consultation Paper concerning the raised duty of care, the Government (at paragraph 22) provides that Section 33 of the Pensions Act 1995 will apply to all matters to which the new duty of care applies. This section prohibits the exclusion or restriction in any instrument or 
agreement of liability for breach of an obligation under any rule of law to take care or exercise skill in the performance of any investment functions where they are exercisable by a trustee of a trust scheme or by a person to whom the function has been delegated under section 34 of the 1995 Act, eg to an FSA-authorised investment manager.

The Consultation Paper indicates (paragraph 23) that statutory exoneration will apply to trustees for the acts or defaults of the persons to whom their powers have been delegated, provided that the pension scheme trustees have fulfilled the new standard of care in relation to the selection, appointment and monitoring of the person appointed. This is similar to the existing statutory exoneration contained in section 34(4) of the Pensions Act 1995. The Consultation Paper also indicates that pension scheme trustees (as currently is the case) will remain liable for the decisions of investment sub-committees.

\section{Increasing the role of the SIP}

Additional requirements have also been placed upon trustees in relation to preparation of the SIP. The SIP was introduced as part of the Pensions Act 1995. The production of the SIP concerns overall investment strategy covering, for example:

- suitability and diversification of investments (section 36 of the Pensions Act 1995)

- the types of investments to be held

- the balance between different kinds of investments

— risk

- the expected return

- the realisation of investments

- the trustees' policy (if any) on socially responsible investment and on voting.

\section{What is the scope of the SIP?}

There is some latitude as to how trustees can comply with the requirements as they are subject to wide interpretation. This may account for the widely varying level of detail contained in SIPs which can range from a short pamphlet to 40 pages!

In order to comply with the statutory requirement to obtain appropriate written advice, production of the SIP is generally undertaken on the advice of the actuary and the investment consultant.

Confirmation that the trustees have prepared the SIP must be given in the annual report and a statement made that a copy is available on request.

(Regulation 6, the Occupational Pension Schemes (Disclosure of Information) Regulations 1996).

\section{Myners' 'super' SIP}

Myners' proposals go well beyond these requirements. Myners' concern is that, as presently constituted, the SIP will not by itself promote proper discussion of the fund's investment strategy.

The review's recommendation was that the SIP should be strengthened so that members gain access to better quality information as a matter of course, and that it should be sent out to members annually.

The Government supported this proposal. It did acknowledge in its response that although the SIP should be available to members, a copy of the SIP did not need to be supplied annually (as originally proposed). The revised principles state that trustees should publish the SIP and should send key information (as opposed to the SIP itself) to members annually including an 
explanation of why there has been any departure from the principles.

\section{What additional information will be provided?}

Turning to the proposed additional information to be provided, the new strengthened SIP would be required to contain the following detailed information for DB schemes. For example:

- the identity of who is taking decisions and why this structure has been selected

— the fund's investment objective

- the fund's planned asset allocation strategy, including projected investment returns on each asset class, and how the strategy has been arrived at

- the mandates given to all advisers and managers

- the nature of the fee structures in place for all advisers and managers, and why this set of structures has been selected.

The SIP may be expected to outline Myners' requirements, explaining what the principles are and the extent of compliance and reasons for noncompliance.

\section{Effect of increased flow of information to members}

It is difficult to see how the increased flow of information to members will assist trustees' decision making. First, what are the members supposed to do with the increased amount of information? Will it be of any practical use to members? Myners observes that most trustees have difficulty in understanding investment concepts, but is there any reason to think that the members would be in a better position? The increased information flow may cause trustees to be over-cautious in their decision-making, as they may feel constrained by the knowledge that their decisions will be scrutinised by the membership.

\section{Investment objectives}

\section{Underperformance}

Myners also recommends that trustees state their attitude to risk and their willingness to accept underperformance due to market conditions. The rationale for adopting this recommendation is not clear. Risk is already covered by the existing requirements of the SIP. Trustees as fiduciaries are not like other investors where there may be a wide range of attitudes to risk. They are locked into the overall objective of the scheme to meet the liabilities to pay benefits and, as such, any risks taken cannot be at the expense of weakening the prospect of reaching that objective. However, underperformance as a consequence of market conditions is a factor outside their control.

Perhaps the point here is what would the trustees' reaction to bad market performance be? Would they feel compelled to alter immediately their investment strategy or would they hold out for a while? Myners is unclear.

\section{Explicit mandates}

Another key recommendation is that investment manager mandates must be made clearer and more explicit. Myners recommends that the mandate should include all financial instruments, unless there is specific justification to exclude a particular class of investments in the circumstances of the fund. This raises the possibility of conflict between the Myners proposals and the principle of freedom of trust. 
The Pensions Act 1995 provides at section 34(1) that trustees have all the power of a beneficial owner of the assets (subject to any express restrictions in the trust deed). It is open to the settlor to include in the trust instrument restrictions upon investment, for example, in relation to self-investment or financial futures. Should the Government interfere in this and prohibit restrictions? Such action could be seen as divesting the employer of a necessary power to enable it to keep some control in a situation where legislation has given trustees almost complete freedom in the investment context. The Government dismissed this concern on the basis that it implies a low level of confidence on the part of the sponsor in the ability of the trustees to manage the fund sensibly and prudently (see paragraph 75 of the Government's response to consultation).

In this regard Myners has provided a timely reminder to investment advisers/trustees, that there are other types of investment instrument available and that in carrying out their duties they should take a broader view of the possibilities, if only then to dismiss them perhaps on grounds that they are not closely enough aligned to fund objectives, or yield uncertain returns and are, therefore, simply too risky. Trustees, in avoiding a particular asset class, should state that they have considered it and explain why they have rejected it.

\section{Timescale for evaluation}

Myners also recommended somewhat controversially that there should be a clear timescale for measurement and evaluation of the manager's performance and that the mandate should not be terminated before the expiry of the evaluation timescale other than for clear breach of the conditions of the mandate or because of significant change in the ownership/personnel of the investment manager.

This could pose difficulties for trustees. Arguably, on this issue the parties should have the freedom to contract their own arrangements. In addition, this proposal would seem to be at odds with the trustees' power under section 47 of the Act and the regulations (the Occupational Pension Schemes (Scheme Administration) Regulations 1996), to terminate appointments of fund managers without notice.

The Government acknowledged these concerns in its response providing that the mandate must not be terminated before the evaluation timescale for underperformance alone.

\section{Performance measurement}

One key element of the Myners Report concerns performance measurement. The Myners Report states that trustees should arrange for measurement of the performance of the fund and make formal assessment of their own procedures and decisions as trustees. The level of detail that needs to be disclosed is not clear. In the SIP, information must be provided concerning who is taking which decisions and why this structure has been selected. Key information from the SIP must be passed to members annually and the results of their monitoring of advisers and managers. The scope of this latter requirement is not clear - 'advisers' could mean all the trustees' advisers (not just investment consultants), as most advisers will have had some (if only indirect) involvement in the scheme's investment process.

The new disclosure principles may be in conflict with the existing legal position as concerns common law disclosure set out in the Londonderry case. ${ }^{9}$ This decision of the Court of Appeal remains good law and establishes 
the principle that the Court will not normally direct trustees to disclose to beneficiaries documents setting out reasons for trustees' decisions.

This is a controversial area and is subject of much wider debate outside of the investment context.

\section{Myners and DC schemes}

The last area that I wish to consider is the application of Myners' principles to DC Schemes. The recommendations are similar to DB schemes in many respects. But some of them, particularly those requiring additional investment information to be given to members, create particular challenges in the DC context.

\section{Clear objectives}

Myners recommends that clear objectives are set for each DC Fund. A key point is that more information will need to come from the trustees to members about choices of funds. Trustees will be required to publish 'their assessments' of the characteristics of each fund vis-à-vis expected returns, risks and so on. They will need to satisfy themselves that 'members' circumstances' have been taken into account and that they are offering wide enough options. It would seem possible that only members' circumstances in very general terms could be taken into account.

The requirement for more information to be passed to members raises several key legal issues.

\section{Current practice - DC fund literature}

In most cases, the literature provided by trustees concerning the individual funds selected has usually been provided by insurance providers, the investment houses or by actuaries. The reason for this is that trustees are concerned not to be found in breach of the restrictions under the FSA 86 (now FSMA 2000) upon giving investment advice/issuing investment advertisements. This remains an area of difficulty for trustees and the ambit of the restrictions in practice remains unclear. Trustees therefore will need to be cautious and take advice as concerns the scope of the information passed to members.

The Association of Pensions Lawyers has proposed that such member information is clearly made the responsibility of an FSA regulated body and not the trustees and that further guidance should be given in this area. Any further guidance should address the issue of trustee liability for member information. Currently trustees may find themselves liable for misleading information passed to members even though the literature is not produced by themselves (although they may not have the expertise to detect this). The Government's response to the Myners consultation did not address this issue.

Aside from the regulatory position, Myners' emphasis on more information throws into relief once again the issue of trustees as advice-givers and their duties in this area.

\section{Duties of trustees as advice-givers}

What are the trustees' duties in statute/common law? Under statute, trustees have very limited duties for the provision of information about investment options.

The position under the general law following such cases as the NHS Pensions Agency v. Beechinor ${ }^{10}$ is that trustees are not under an obligation to give advice.

However, it is true that where trustees give additional information to members, it must be correct or else they will be held responsible. In the case of Miller $v$. 
Stapleton, ${ }^{11}$ Carnwath J said (following the reasoning in the case of Hamar and another $v$. The Pensions Ombudsman ${ }^{12}$ that:

'Even if pension trustees are under no legal duty to give advice to beneficiaries, it is generally good practice for them to do so; and, when they do, it should be as clear and accurate as possible.'

Myners' recommendations appear to be pushing trustees into a situation where they could become more akin to investment advisers. There are currently regulatory problems with that position which Myners did not fully address in his report.

Even if that issue is overcome, how far should trustees go in directing members? Should trustees have a greater advice-giving role? The dilemma for trustees is that they are still vested with the assets and have legal responsibility for their prudent investment but choices are being made by third parties, the members.

Members tend to be conservative in their approach to investment choices because the impact of bad investment performance will have a direct effect upon the value of their funds.

Some commentators have suggested that the solution to this problem is that Myners does not go far enough and that trustees should get involved in directing and monitoring members' investment choices and take action to change the content of member literature where unexpected patterns of behaviour are revealed. Such a monitoring role does fall beyond trustees' remit at the moment and would stray well within the arena of investment-advice giving.

This issue is becoming more and more topical as a consequence of the shift from DB provision to the assumption of responsibility for pension provision and choices by individuals through DC schemes, group personal pension plans and stakeholder. Perhaps a more realistic approach would be to heighten the value to members of seeking their own independent investment advice. Ultimately, it may be that we need legislation to clarify this area of responsibility for investment choices.

\section{Conclusions}

Trustees are now in the throws of aligning their practices and skill levels to comply with Myners' recommendations.

Government assessment of the effectiveness of the principles in bringing about change will begin in March 2003. The existing legislative framework currently restricts trustees' ability to comply with all Myners' principles in particular in relation to trustees' decision-making and delegation functions. More certainty will not be achieved in this area until new legislation is published next year. In the meantime, trustees should review their investment procedures, practices and expertise levels in conjunction with their advisers and establish an outline 'business plan' to demonstrate that they are taking reasonable steps to achieve Myners compliance.

\section{(C) Kate Richards}

\section{References}

1 The Independent, 7th March, 2001.

2 Department of Labor, 44 FR 37225, 26th June, 1979.

3 (1886) 33 [ChD 347, 358].

4 [1980] Ch 515, 531.

5 [1985] Ch 270, 289.

6 [1988] 1 WLR 167, 171.

7 [1993] 1 WLR 1260.

8 See section 19(1) of the Financial Services and Markets Act 2000 FSMA, Article 37 of the Regulated Activities Order and Schedule (4) of the Financial Services and Markets Act 2000 (Carrying on Regulated Activities by Way of Business Order) 2001.

9 Re Londonderry's Settlement [1964] 3 All ER 855.

10 [1997] OPLR 99.

11 [1996] PLR 67

12 [1996] PLR 1. 